\title{
THE EFFECTS OF ADMINISTRATIVE REFORMS ON THE DEVELOPMENT OF A SETTLEMENT IN THE GREAT PLAINS DURING THE ERA OF DUALISM
}

\author{
Tamás Fülöp $p^{1 *}$ \\ J John von Neumann University, Hungary \\ https://doi.org/10.47833/2021.1.ART.011
}

\section{Keywords:}

urban development, settlement modernization, dualism, public administration history, archontology

\section{Article history: \\ Received 31 Marc 2021 \\ Revised 3 Apr 2021 \\ Accepted 8 Apr 2021}

\begin{abstract}
In my study, I examine the connections between settlement development and the Hungarian public administration reform at the end of the 19th century through the modernization efforts of a city in the Great Plain. In the course of my research, contemporary city protocols, official mayoral correspondence, local and national administrative legislation, as well as economic and statistical data provided primary sources. In the course of my analyzes, I came to the conclusion that there is a significant correlation between the county settlement structure, city function and county seat role formed by the dualism-era administrative reform, and the dynamic development of some settlements. An example of this is the settlement history of the examined Great Plain county seat.
\end{abstract}

\section{Introduction}

The dynamic development of Hungarian urban areas at the end of the 19th century and the beginning of the 20th century is closely connected to the modernisation of administration during the era of Dualism. Spatial planning and change in the administrative role of the settlements had a positive impact on the urban development regarding the administrative, political and macroeconomic conditions; all these changes meant numerous new economic opportunities for towns and urban areas. Szolnok, becoming a county capital in 1876-ban in the Great Plain, is one of these settlements. It can be clearly stated that in the four decades between 1876 and 1914 the special features of settlement development - the initiation of administrative, economic, social changes, reforms; the expansion of urban functions; the sings of urbanisation in the infrastructure and settlement pattern, the foundation of the architectural heritage that still characterises the town prove that the contemporary city authorities and inhabitants could take the advantage of the positive geo-economic, political, administrative and financial opportunities. The achievements prove that the town could meet the challenges of each era and take a great step forward in urban development even in its own context. (Szilágyi 2016.)

During these decades the town of Szolnok - mainly thanks to the contemporary decision makers, local experts, clerks and entrepreneurs - seems to take advantages of development opportunities and could very well adapt to the changing external conditions and achieve a significant development while preserving and expending its subregional role despite all the hardships. Even though Szolnok had excellent facilities, in 1874 it only had the status of municipality, and this market town-like „must county” capital became a modern and attractive town, an economic, financial and cultural centre as a result of urbanisation between 1876 and 1944. (Fülöp 2020) This development phase rooted in the transportation, eco-geography and industrial potentials; open atmosphere;

\footnotetext{
* Corresponding author: Tel.: +36 3051923 10;

E-mail cím: rektor@uni-neumann.hu
} 
social, cultural and religious tolerance of the town. Moreover, Szolnok could benefit from the extending administrative opportunities. All the aforementioned factors take us to the conclusion that the settlement could very well adapt to modernization opportunities in each era, respond to the challenges of historical changes, and attract, educate and keep those experts who were able to support the development in several fields of administration, town leadership, economy, society coordination, education, culture, health care, sport and tourism. The beginning of these processes is the administration reforms and receiving the county capital status during the dualism, which resulted in extending and strengthening the town's administrative role and was the catalyst of the development.

\section{Administration reforms and spatial planning at the end of the 19th century}

In the decades after the Reconciliation the conservative-liberal political forces aimed at a gradual centralisation process in administration in order to develop a modern administration system. In the 1870s both the governing Liberals and the parliamentary opposition set up the goal of developing a modern, western-European civil institution system. This tendency meant developing a centralised administrative system that was quite the opposite of the traditionally extensive municipality governing system. The government actions to endorse professionalism were very often opposed by Independence Party favouring municipalities and the Hungarian counties. The counties - referring to their centuries-old historic roles to defend the constitution and the independence of the country against absolutism - insisted on keeping up their extensive self-government and autonomy. The conflict between these two tendencies, alongside with the growing assertion of the state, ran through the whole era.

The XLII. Municipality Law in 1870 initiated ground-breaking changes in the development of modern civic administration system. By establishing municipalities, the law eliminated the feudal traditions in the administration, laid the new foundations of self-government and medium-level of the administration fixing municipality power, system, election system, means of government control and influence. (Sarlós 1976) The municipalities - preserving their own authority, restricted internal autonomy and political opinioning rights - wielded self-governing power by executing parliamentary laws and governmental regulations, and transmitted state administration.

The Law of 1870 fundamentally redefined the relationship between the government responsible to the parliament and municipalities representing local interests, just like county authority and operation. Although the main aim of the law was to restrict local government rights and extend the influence of the central executive power, meeting local municipalities interests in autonomy and the centralisation efforts of the state could be achieved in the fragile, give-and-take system of Dualism. This compromise did not hurt constitutional rights and ensured the basic conditions of harmonious functioning aroused by economic, social reforms and modernisation needs. Not only did this new municipal administration meet the expectations of modernisation and was able to guarantee the efficient operation of the municipalities but was also suitable to efficiently support the necessary economic and social reforms.

The law ordained the so called intermediate administrative units having the same or very similar legal status to counties - e.g., free towns, seats and Jászkun District - to belong to municipalities. (Zala megye archontológiája 2000) As a consequence, the free jasz and nagykun settlements, which were fundamental parts of the future Jász-Nagykun-Szolnok County, were subjects to the new administrative system. The 1870 Law on Municipalities basically ceded the autonomy of Jászkun District, although free districts interditigating into county system of feudal origin since 1745 could preserve their territorial integrity; the process of integrating the free districts into the state administrative system ended in 1876 with the establishment of Jász-Nagykun-Szolnok County.

According to Article 2 XLII. Law of year 1870 a new body was established, partly elected to enforce authority laws representing municipalities in Jászkun District, and this body was similar to the municipalty committees replacing the feudal noble general assemblies. After registering the virilists, who paid the highest taxes, local elections were held in all jasz and nagykun settlements on 
12 December 1872. After ending the legal investigations, the Municipality Committee of Jászkun District started its work on 11 January 1872. (Seres Péterné 1975) The structure and functions of the civil servant body in Jászkun District executing government regulations and local council orders were developed following the county samples, except for the fact that executive officers in the District could preserve their previous titles. The commissioners of police (sheriff) duties delegated by the government were executed by Miklós Kiss, the parliamentary representative from Kecskemét, who was inaugurated on 21 October 1873 . The law very thoroughly regulated the election and nomination process, duties and responsibilities of central and external (district) officials, operating and servant staff. The mandate of officials in Jászkun District became due right before the law was enacted, and the Minister of Internal Affairs did not give permission to elect the new district officers not much before the enactment of the law in 1870. Therefore, the officers elected in 1867 stayed in office because of necessity did resign only just before the new elections, on 9 January 1872 . The district municipality officials were elected for 6 years after the organisational duties by the municipality committee at the general assembly on 9-10 January 1872. The following 33people were elected to the central officer crops: Imre Balogh vicar, József Kerek town clerk, Ferenc Nagy, Imre Szivák, Sándor Hajdú notaries, Antal Bozóky solicitor, János Pethes accounting general, Endre Baky, Illés Mészáros vice accounting generals, Kálmán Keller treasurer, dr. Antal Orbay head physician, Péter Horkay first engineer and József Szappanos vet.

The development of municipal administration and the reforms in elementary public administration continued in 1871 , and the status of settlements not having municipal rights was resolved by enacting the municipality law. Article XVIII of Law year 1871 regularized the administration of small settlements and municipalities in accordance with the county organization, on its analogy. The law grouped the settlements into three categories: towns with settled council, municipalities and small settlements. Towns with settled council had the most extended scope of duties; these settlements - unlike municipalities and small settlements - were no subjects to the municipal administration; their leading official was the mayor, who had equal rights to the high sheriff of the municipality. The scope of duties of municipal administration and the legal practice of municipality rights changed in the same way. The municipal rights were practised Municipal rights were practised by the representatives, half of whom were elected, and half of whom were virilists, or through the general assembly. Executive power belonged to the prefecture that was commissioned by the representatives.

The original organisation of Jászkun District settlements developed after redemptio, municipalities carried out the redemption as legal entities, and as such received those privileges that they could exercise through judges and the city council. The autonomy of the settlements in Jászkun District was extended to numerous areas in administration before enacting municipality and township law; general assembly and council of the settlements in the district often functioned as high sheriffs, the district court, chancery, land register authority, while their prefectures even acted as county police authority. In 1867 within Jászkun District there existed 25 autonomous settlements, each of which had a very complex administrative authority. When the status of the settlements was redefined, three municipalities were developed in Jászkun District - preserving the term „district” in their names -: the centre of Kiskun district became Kiskunfélegyháza, that of Nagykun district became Karcag, while the town of Jászberény became the centre of Jász. (Seres Péterné 1975) Within the district nine towns with settled council (Jászberény, Félegyháza, Karcag, Kisújszállás, Kunhegyes, Kunszentmárton, Túrkeve, Halas and Árokszállás) and 16 large villages were developed. Kunhegyes, Túrkeve, Kunszentmárton and Kisújszállás as towns with settled council and Madaras as a large village belonged to Nagykun district (municipality) that later was annexed to Jász-Nagykun-Szolnok county, the town of Árokszállás, of which status was not settled then, and large villages of Felsőszentgyörgy, Fényszaru, Jákóhalma, Apáti, Ladány, Dózsa, Mihálytelek, Kisér and Alsószentgyörgy belonged to Jász district (municipality). This dictrict and municipality division was untouched until the enactment of Law on Spatial Planning in 1876. 


\section{Spatial Planning in $\mathbf{1 8 7 6}$ and the establishment of Jász-Nagykun-Szolnok county}

The Article XLII of Law year 1870 - although it did not eliminate all forms of regional and administrative separation, therefore did not have an effect on the autonomy of Jászkun District basically regulated the scope of duties of municipalities, the election system and functions of the general assembly, and the sheriff's, deputy-lieutenant's and other officials' duties. The main effort of the government of Tisza Kálmán coming into power in 1875 was to gradually expand state authority into fields of county public life. It is not by accident that the conflict between „independent county" and central state power had on impact on county public life during the whole era. Putting local county duties gradually under state control continued in the second half of the decade. Governmental positions in the fields of public health, tax policy, public schools were strengthening, while counties lost their judicial and arbitrary rights. A new step to narrow the scope of municipalities was to enact the law on setting up administrative committees. Article VI in Law year 1876 tried to balance the state management starting to operate after the Reconciliation and the traditional municipal administration system so that the government could directly control law enforcement and the implementation of local regulations through a body empowered with a lot of rights. According to the law all municipal officials at the territory of the municipality „was to obey” to the general assembly, but they could veto the decisions of the general assembly and could have a say in the management of state institutions at territory of the municipality. This body incorporated a significant proportion of intermediate level municipality duties through several sub committees, and the government could have a direct influence on the functions of municipalities through its president, the sheriff. According to the law the central power could delegate 6 persons (the sheriff, the tax inspector, the school inspector, the head of the post office, the head of the Office of Construction and public prosecutor) into the county general assembly of 21 members. Keeping up the pretence of autonomy, the general assembly, which was independent from the government in theory, could delegate 10 persons into the committee, while the other 5 members (deputy-lieutenant, town clerk, solicitor, head physician, the president of the chancery) were also officials elected by the county. The general assembly intersected between the government and the municipality had an extended power in the everyday life of the municipality, since this was the body that checked law enforcement, government regulations, county ordinance; ruled, controlled and called county officials and municipality staff to account; so it represented both state power and local administration. As a consequence of this regulation, the number one representative of county interests is the sheriff appointed by the Home Secretary, while the municipal committee had a great autonomy against general assembly, could withdraw resolutions of the deputy-lieutenant or the settlements without letting the county representatives taking any sanctions against this body. This solution could create such a rural administrative structure that mainly represented the will of the executive power and the former county autonomy perished except for fragments.

The enactment of laws organising municipalities and large villages and establishing administrative committee was one of the stations of the process to revise the role of counties still having feudal characteristics and other administrative units having autonomy. During the implementation process it turned out there were quite a lot of self-governing units among the newly established municipalities that could not meet expectations of efficient and sustainable administration due to their location, settlement composition and territory. The administrative law did not influence the historically inherited territorial division of intermediate level administrative units in 1870. Therefore, there were great discrepancies between the size of territories of certain counties all over the country, and the borders of certain municipalities, the municipal network, municipal centres did not follow the undergoing changes. (Zala megye archontológiája 2000) The discrepancies in administrative duties were due to territorial disproportion, the differences in population, tax payments of settlements, and they meant a growing problem for the state. An example illustrating the territorial disproportion is that there existed 10 different administrative (political, electoral, judicial, financial, educational, postal, telegraph, public work, monarchy military management and army) units simultaneously. (Seres Péterné 1975) The government had to keep in touch with administrative units organised according to 6 different territorial definitions (58 counties, 
14 seats, 5 countries, 4 districts, 47 free royal towns and 25 municipal towns), all of which had different traditions. The most typical example for the old-fashioned, pointless territorial division was Jászkun District as it contained nine smaller territories that were separated from each other by other municipalities and was also divided by the River Tisza as a natural borderline. This is the reason why we can state that Article XXXIII. in year 1876 regulating the territories of municipalities and establishing Jász-Nagykun-Szolnok county was an integral of the process to extend state authority, ceding the previous territorial division and fragmentation of municipalities.

Article XXXIII No. 17 of year 1876 on the spatial planning of municipalities is to establish JászNagykun-Szolnok county. The area of the new municipality Jászság, Nagykunság and the parts of Heves and Külsö-Szolnok county that laid ont he left bank of the River Tisza, „except for the large villages of Tisza-Füred, Tisza-Igár, Tisza-Örvény, Tisza-Szöllös, Tisza-Örs and Nagy-Iván belonging to Eger municipality, which stay in Heves county". The area on the right bank of the River Tisza lying south from large village of Pély and large village of Jánoshida split from Pest-Pilis-Solt-Kis-Kun county were annexed to the new county. The town of Szolnok became municipality capital.

The establishment of Jász-Nagykun-Szolnok county with Szolnok as its capital and the establishment of further twenty new counties listed in this law could be regarded as the final step of the administrative reforms that had started at the beginning of the 1870s. As we can see, the regulation of the county municipalities operation and appointing elementary level (large village) administrative tasks were already subject to legislation at the beginning of the 1870 s and put into practice; still the enactment of the law to finalise this process and sanction the spatial planning of municipalities could be taken the agenda in the Parliament only in the middle of the decade. After the Redemption there was a long way taking us to permanently line out the borders of this county in the middle of the Great Plain; when the disputes about the spatial planning of municipalities started nobody knew which settlements with which capital town will be melted by the decision makers. It seemed to be a challenge to fit Jászkun Disrict with its diverse territorial structure, historical privileges and area divided by the River Tisza into the new county system, and some other problems such as ceding the anomalies, maladministration due to diverse territorial structures had to be solved, and a more proportional territorial, residential and, as a consequence, tax-paying division were to be established. (Bánkiné Molnár 1995)

Finally, Jász-Nagykun-Szolnok County was established in 1876 - after year-long political struggles - and it was formed from the jász and nagykun settlement of former Jászkun District, and the settlements alongside the Tisza in Heves and Külsö-Szolnok counties. The cessation of the historical autonomy and century-long privileges of Jászkun District, one of bases of the newly-formed county, at the end of the 1860s and the beginning of 1870s was simultaneous to the judicial reforms, the unification in the administration and the restructuring of large village local councils. (Bánkiné Molnár 2005) The government appointed Miklós Kiss the new sheriff to be head of the District on 15 May, 1873 (he was inaugurated on 21 October 1873), then in the very same year the spatial planning of the municipalities, marking of the new county borders as the final stage of the process was initiated. Between 1873 and 1876 several spatial planning conceptions, county plans appeared and they represented the particular interests of the historically intertwining counties that had different public law status. There were several suggestions on county planning- e.g. in 1874 the idea to establish Kun and Jász Counties as two independent ones came up - between 21 December, 1873 when Home Secretary County Gyula Szapáry announced his suggestion and 6 May, 1876 when Kálmán Tisza did his, however, the most debated issue was around the capital of the new-born Jászkun County. Development of the new municipality structure and the accelerating economicsocial reforms of Dualism happened simultaneously in the last third of the 19th century. Therefore, gaining county capital status not only had a political significance - including state- and municipalityrun constructions, extending administrative and judicial power, growing agglomeration -, but it also had several economic, infrastructural and social benefits. (Cseh 1993/1.)

The case of developing a new municipality in the middle of the Great Plain was put on agenda in the House of Representatives at the beginning of June 1876. During the negotiations it became obvious that the name of the new municipality would be Jász-Nagykun-Szolnok County, and its capital would be Szolnok that formerly belonged to Heves and Külsö-Szolnok Counties. In the first draft proposed by Szapáry in 1873 Szolnok could not even have been mentioned as a would-be county capital as it had the status of a large village then. Still, this fact could not prevent the 
inhabitants in Szolnok to declare that this settlement „is destined and completely entitled to be the capital of the new county due to its location, land, railway and water transport, commercial and industrial development and intellectual advancement".

On 28 February, 1874 Ferenc Hubay, the future mayor at a city council session suggested that the representatives send a petition including the aforementioned reasons to get the county capital status to the Parliament. (Jász-Nagykun-Szolnok 1890) The decision of Szolnok city council to establish the dynamically developing Szolnok as a town with settled council - with the agreement of the Home Secretary -should be considered as a part of the struggle to become a county capital, although the town had financial difficulties. The renewed city council of Szolnok, the town with settled council elected Ferenc Hubay to be its mayor on 30 March, 1874. The most highly-ranked man and its representative body took every effort from the beginning to make Szolnok the county capital of the newly established county. Despite the hard and unsettled economic conditions, both the city council and representatives - beyond referring to the economic-transportation role of Szolnok - were ready to make financial sacrifices. The contemporary city leadership realised that the future development of Szolnok was very much dependent on whether it became a county capital or not. Therefore he acted with great commitment to take the advantage of Szolnok's economic conditions (railway, crossing place, central position, and strengthening industry) to make it the centre of the new municipality overtaking those jasz and nagykun settlements that had seeming cultural and economic advantage in the 1870s. (Cseh 1993/1.) Szolnok belonging to Heves and Külső Szolnok County - although Jászberény and Karcag were more modern regarding infrastructure citizenship than this town along the Tisza -, had so high commercial and industrial achievements at the beginning of the 1870s which did not rank the town behind other towns in Jászkun District, most of which did not any social and economic potentials.

The government initiated to make a Szolnok a county capital for the first time on 2 September 1874 , and the town was expected to contribute to the construction of the new county capital town hall. The council made a suggestion to the representatives „that the town should offer Zöldfa Inn for the county in case Szolnok is designated to be the county capital, and [...] town should call Szolnok citizens to contribute to the construction". The town of was willing to belong to the county Szolnok only if it is the county capital and was not willing to join any other counties. Szolnok inhabitants had heated reluctance in 1873 against an independent Kun County with Karcag as a county capital and in 1874 against Jász County with Jászberény as a county capital. This fight for prestige ended up with the city representatives declaring on the very same day - following the city council initiative that the question of county capital „is a question of life and death, and is willing to have any sacrifice to establish a county with Szolnok as its capital during the process of reorganising the counties". The town threw not only their influential parliamentary representatives into the scale in the fight against the competing settlements, but wanted to outbid them in the financial support. That is why the city council decided to offer „Zöldfa Inn owned by the town with roll call votes [...] by simple majority [63 yes and 1 no vote]" free of charge to the county in case Szolnok becomes the county capital.

In spring 1876 the events accelerated as the dispute of the bill in the Parliament was due, the government introduced the bill on spatial planning in March, and the final formation of the new administrative system started. The updated question on the rearrangement of the counties aroused the question on the location of the county capital again; this fact inevitably led to intense lobby activities. In this fight Szolnok was represented by a new mayor, the most important entrepreneur, István. (Scheftsik 1935.), (Cseh 2006) The new mayor followed his predecessor's, Ferenc Hubay's conception to make Szolnok the county capital - by mobilising members of Parliament and making a pledge by offering the building site of the new county hall. Szolnok's new leader, István Scheftsik, full-heartedly headed the fight for the position of county capital. Only a month after the election for the mayor, the city council had an extraordinary general assembly on 26 March 1876 - preparing for the final battle in the spatial planning war -,to take the necessary steps in time" during the parliamentary debate on the law. István Scheftsik, the mayor informed the city council what concrete steps were taken to make Szolnok the new county capital by the city representative and the representatives in the Parliament. He referred to the fact that Szolnok had already made a pledge several times in assembly resolutions in 1874 and 1875 ,to ease to find available rooms for the offices of the new county or even the state". Nevertheless, the previous generous offer then had to 
be realised as the events accelerated. The city council came to the conclusion that „Szolnok is without the doubt the most suitable towns among the neighbouring ones thanks to its position in the railways and along the Tisza, which resulted in high importance in commerce and traffic". However, in order to "indicate a friendly gesture towards the developing new county, and the readiness to cooperate in finding the right location"; they made a clear statement in the legislative body to be willing to become a county capital. The city council took another resolution stating that they are willing to offer a building plot of 1000 acre in the city centre to build the new county headquarters, 30000 forints in cash, and one-year long communal work to construct the new building.

Even though „the financial situation of Szolnok was not very promising”, Heves and KülsöSzolnok County, which was the superior authority of the town at that time, did not hinder this proposal. Seeing that the city representatives in Szolnok took a common ground in this question, and being sure that "there is no reluctance to make - no matter how big - sacrifices”, the attorney general of Heves County called the offer "a good investment”, which will be paid back in the long run, and he was willing to support Szolnok in its attempts. Based on the aforementioned facts, István Scheftsik, the mayor of Szolnok and the legal representative of the settlement wrote the followings in the handover agreement: „the proprietary rights [...] of the so-called 'Zöldfa Inn' with its entire inlot and all the buildings on it - which are the property of Szolnok - should be [...] entitled to JászNagykun-Szolnok County, and it is handed over to the county as a freehold without having to pay any charges". The latter events demonstrated that the city council of Szolnok at this general assembly showed a high political responsibility, far-sighted thinking and took tremendous efforts. The valuable inner-city building lot, the tremendous donation to the building costs, the offer of one-year long communal work, and the temporary accommodation of county offices were unsurpassable by the rival settlements.

The „extraordinary sacrifices” and the year-long struggle were not in vain. István Scheftsik István, the mayor announced on 24 June, 1876 at the city council assembly that "the legislative body of Hungary designated the town of Szolnok to be the capital of Jász-Nagykun-Szolnok County". The celebrating town sent a thanking letter with a five-member delegation to Kálmán Tisza prime minister, the House of Representatives, and István Gorove, count Gyula Szapáry, László Kovács, Gyula Gullner, Nándor Horánszky, Károly Kövér parliamentary representatives, who did a lot to make Szolnok a county capital. The establishment of Jász-Nagykun-Szolnok County with Szolnok as its capital arouse the practical question of accommodating the county offices. On 20 August, 1876 Szolnok city council had an extraordinary assembly with István Scheftsik mayor, where Miklós Kiss, the appointed sheriff of the county also participated. The sheriff in his speech asked the city council to appoint suitable rooms for the county offices and the city council and turn them over to the county in agreement with the previous offers „as the establishment of Jász-Nagykun-Szolnok County with Szolnok as a capital is coming to action soon". The town of Szolnok gave a written resolution to the sheriff that "Szolnok is ready to fulfil all its promises and offer in order to be designated the capital of the county - as it has already proven so".

Becoming a county capital opened new ways of modernisation for the town. The building of the county hall and the development of the county administration started in 1876 . The extension of administrative role was followed by economic development, industrialisation, growth in population and significant building constructions in Szolnok. This development could only be belated by the consequences of World War I and Trianon Peace Treaty. The town development got new dynamic in the second half in the 1920s, and Szolnok really could go through significant economic and social changes in the seven decades between its becoming a county capital and World War II; the general dynamic of economic and infrastructural development, dynamic of becoming a county capital and the conscious spatial planning between the two world wars were all represented in this process. (Fülöp 2014) The county capital made up the leeway and all the disadvantages due to the built environment, map, urban infrastructure, public works, services offered to the inhabitants and settlers despite all the declines and crises that were very obvious when the county was established; as a result Szolnok could turn into a modern city in the middle of the Hungarian Great Plains from a county capital established only with administrative means. 


\section{Acknowledgement}

This research is supported by EFOP-3.6.1-16-2016-00006 "The development and enhancement of the research potential at John von Neumann University" project. The Project is supported by the Hungarian Government and co-financed by the European Social Fund.

\section{Bibliography}

[1] BÁNKINÉ Molnár Erzsébet: A Jászkun Kerület igazgatása 1745-1876. A Jász-Nagykun-Szolnok Megyei Múzeumok Közleményei 51. Szolnok, 1995. 226. p.

[2] BÁNKINÉ Molnár Erzsébet: A jászkun autonómia. Szeged, 2005. 264-267. p.

[3] CSEH Géza: Megyeellenes partikuláris mozgalom a Jászkunságban. In.: Jászkunság, XXXIX. évf. 1. 1993. február. 19-28. p. Hivatkozott rész: 19. p.

[4] CSEH Géza: Három nemzedék. Adatok a szolnoki Scheftsik család múltjából. In.: ZOUNUK 21. A Jász-NagykunSzolnok Megyei Levéltár Évkönyve (Szerk.: Zádorné Zsoldos Mária) Szolnok, 2006. 81-118. p. és 87. p.

[5] FÜLÖP Tamás: Megyeszékhelyből város. Szolnok város településfejlődési törekvései a megyeszékhellyé válás és a második világháború közötti évtizedekben. Neumann János Egyetem, Magyar Nemzeti Levéltár Jász-NagykunSzolnok Megyei Levéltár, Szolnok, 2020. 439 pp.

[6] FÜLÖP Tamás: Négy kudarcra kárhoztatott kísérlet. Szolnok város kérelmei törvényhatósági jogú várossá válás tárgyában 1922-1947. In: ZOUNUK A Jász-Nagykun-Szolnok Megyei Levéltár Évkönyve, (2014) 28. sz. 205-250. p.

[7] Jász-Nagykun-Szolnok Politikai, társadalmi, közművelődési és szépirodalmi hetilap. Szolnok, 1890. júl. 6.

[8] SARLÓS Béla: Közigazgatás és hatalompolitika a dualizmus rendszerében. Akadémiai Kiadó, Bp., 1976. 26. p.

[9] SCHEFTSIK György (szerk.): Jász-Nagykun-Szolnok vármegye múltja és jelene. Pécs, 1935. 333-334. p.

[10] SERES PÉTERNÉ: Jász-Nagykun-Szolnok megye kialakítása. Levéltári Füzetek 2. Szolnok Megyei Levéltár. Szolnok, 1975. 13. p.

[11] SZILÁGYI Zsolt: Isten veled fejlődésmodell! Kecskemét alkalmazkodásának történeti sajátosságai. In: FORRÁS 48. évf. 2016. 7-8. szám 36-59. p.

[12] ZALA MEGYE ARCHONTOLÓGIÁJA (Szerk.: Molnár András) Zala Megyei Levéltár, Zalaegerszeg, 2000. 124. p.

\section{Legislation}

[13] 1870. évi XLII. tc. A köztörvényhatóságok rendezéséről. In.: 1869-1871. évi törvényczikkek. Corpus Juris Hungarici. Magyar Törvénytár 1000-1895. Millenniumi emlékkiadás. (Szerk.: Márkus Dezső) Franklin-Társulat, Bp., 1896. 211221. p. (A törvénycikkely a továbbiakban: 1870 . XLII. tc.)

[14] 1871. évi XVIII. tc. A községek rendezéséröl. Magyar Törvénytár 1869-1871. évi Törvényczikkek. Corpus Juris Hungarici. (Szerk.: Márkus Dezső) Magyar Törvénytár 1000-1895. Bp., 1896.

[15] Magyar Törvénytár 1869-1871. évi Törvényczikkek. Corpus Juris Hungarici. (Szerk.: Márkus Dezső) Magyar Törvénytár 1000-1895. Bp., 1896. 211-221. p.

[16] Magyar Törvénytár 1875-1876. évi Törvényczikkek. Corpus Juris Hungarici. (Szerk.: Márkus Dezső) Magyar Törvénytár 1000-1895. Bp., 1896. 320-336. p.

\section{Referral sources}

[17] MAGYAR NEMZETI LEVÉLTÁR JÁSZ-NAGYKUN-SZOLNOK MEGYEI LEVÉLTÁRA (MNL JNSZML) JásZkun Kerület kgy. jkv. I-3/1872.

[18] MNL JNSZML Szolnok város Közgyűlési jkv. 1867. júniustól 1875 végéig. 18/1874. 1874. február 28.

[19] MNL JNSZML Szolnok város Közgyülési jkv. 1874. márc. 30.

[20] MNL JNSZML Szolnok város Közgyülési jkv. 1867 júniustól 1875 végéig. 28/1874. 1874. márc. 23.

[21] MNL JNSZML Szolnok város Közgyülési jkv. 1867 júniustól 1875 végéig. 2/1874. 1874. márc. 30.

[22] MNL JNSZML Szolnok város Közgyülési jkv. 1867. júniustól 1875 végéig. 22/1875. 1875. ápr. 12.

[23] MNL JNSZML Szolnok város Tanácsülési jkv. 1874. 252/1874. 1874. szept. 2.

[24] MNL JNSZML Szolnok város Tanácsülési jkv. 1874. 253/1874. 1874. szept. 2.

[25] MNL JNSZML Szolnok város Közgyülési jkv. 1867. júniustól 1875 végéig. 61/1874. 1874. szept. 2.

[26] MNL JNSZML Szolnok város képviselötestület kgy. jkv. 38/1876. 1876. március 26.

[27] MNL JNSZML Szolnok város képviselőtestület kgy. jkv. 38/1876. 1876. március 26.

[28] Heves és Külső-Szolnok vármegye kgy. jkv. kivonat. 156/XIV./1876. 1876. június 12. MNL JNSZML Alispáni iratok 1876-1894. Cs. 2. 16.

[29] Szolnok város telekátadási okirata. Szolnok, 1876. július 11. MNL JNSZML Alispáni iratok 1876-1894. Cs. 2. 16.

[30] MNL JNSZML Szolnok város képviselőtestület kgy. jkv. 74/1876. 1876. június 24.

[31] MNL JNSZML Szolnok város képviselötestület kgy. jkv. 121/1876. 1876. augusztus 20. 